\title{
Performance of Solid Oxide Fuel Cells with Direct Internal Reforming of Methane
}

\author{
Young Jin Kim and Hyung-Tae Lim ${ }^{\dagger}$ \\ School of Materials Science and Engineering, Changwon National University, Changwon 51140, Korea \\ (Received July 24, 2015; Revised August 5, 2015; Accepted August 6, 2015)
}

\begin{abstract}
Performance of solid oxide fuel cells (SOFCs), in comparison with that under hydrogen fuel, were investigated under direct internal reforming conditions. Anode supported cells were fabricated with an Ni+YSZ anode, YSZ electrolyte, and LSM+YSZ cathode for the present work. Measurements of I-V curves and impedance were conducted with S/C (steam to carbon) ratio of $\sim 2$ at $800^{\circ} \mathrm{C}$. The outlet gas was analyzed using gas chromatography under open circuit condition; the methane conversion rate was calculated and found to be $\sim 90 \%$ in the case of low flow rate of methane and steam. Power density values were comparable for both cases (hydrogen fuel and internal steam reforming of methane), and in the latter case the cell performance was improved, with a decrease in the flow rate of methane with steam, because of the higher conversion rate. The present work indicates that the short-term performance of SOFCs with conventional Ni+YSZ anodes, in comparison with that under hydrogen fuel, is acceptable under internal reforming condition with the optimized fuel flow rate and S/C ratio.
\end{abstract}

Key words : Solid oxide fuel cells, Internal reforming, Alternative fuel

\section{Introduction}

$\mathrm{S}$ ince a typical solid oxide fuel cell (SOFC) operates at a high temperature above $700^{\circ} \mathrm{C}$ and is composed of $\mathrm{Ni}+$ YSZ cermet anode, no additional expensive catalyst for internal reforming is required while having a high durability against impurities $\left(\mathrm{CO} / \mathrm{CO}_{2}\right)$ in the fuel unlike a lowtemperature type fuel cell (PEMFC). Such characteristics of SOFC allow diversification of alternative fuels other than hydrogen as well as direct internal reforming. From a systems viewpoint, omission of an external reforming apparatus is allowed so that a simple system configuration and high efficiencies may be achieved. ${ }^{1)}$ Due to such advantages of the SOFC, studies are being actively conducted in recent times where changes in the corresponding performance and durability are evaluated/analyzed by directly applying carbonbased fuels (city gas, coal gas, biogas, etc.) to the SOFC. ${ }^{2-11)}$

Most of city gas and refined biogas consists of methane, and main processes of internal reforming of methane are shown in Fig. 1(a) and Fig. 2(b), for steam and dry reforming, respectively. ${ }^{12)}$ In the former case, when 1 mole of methane $\left(\mathrm{CH}_{4}\right)$ and 1 mole of steam $\left(\mathrm{H}_{2} \mathrm{O}\right)$ are supplied to the SOFC anode(Ni surface), conversion occurs to 3 moles of hydrogen $\left(\mathrm{H}_{2}\right)$ and 1 mole of carbon monoxide $(\mathrm{CO})$, while the converted gas is transformed to $\mathrm{H}_{2} \mathrm{O}$ and $\mathrm{CO}_{2}$ by an electrochemical reaction of combination with oxygen ions deliv-

${ }^{\dagger}$ Corresponding author: Hyung-Tae Lim

E-mail : htaelim@changwon.ac.kr

Tel : +82-55-213-3716 Fax : +82-55-262-6486 ered from the anode through the electrolyte producing electricity and heat. Meanwhile, when the fuel cell is under an open circuit condition (without the oxidation reaction at anode), 1 mole of $\mathrm{CO}$ produced by steam reforming together with 1 mole of $\mathrm{H}_{2} \mathrm{O}$ can be converted to 1 mole of $\mathrm{CO}_{2}$ and 1 mole of $\mathrm{H}_{2}$ by water gas shift reaction. As a result, 1 mole of $\mathrm{CH}_{4}$ can produce a maximum of 8 moles of electrons. In the case of steam reforming, it is accompanied by $+206 \mathrm{~kJ} /$ mol of endothermic reaction, while being accompanied by $42 \mathrm{~kJ} / \mathrm{mol}$ of exothermic reaction in the case of water gas shift reaction. In the case of dry reforming, 1 mole of $\mathrm{CH}_{4}$ and 1 mole of $\mathrm{CO}_{2}$ react to produce 2 moles of $\mathrm{CO}$ and 2 moles of $\mathrm{H}_{2}$ accompanied by $+261 \mathrm{~kJ} / \mathrm{mol}$ of endothermic reaction. The produced $\mathrm{CO}$ and $\mathrm{H}_{2}$ are used as a fuel and can produce electricity while being electrochemically oxidized. Since both steam and dry reforming reactions are endothermic in this way, effective thermal management may be implemented upon operation of the fuel cells if such reactions are used properly. ${ }^{13,14)}$

Although SOFC stacks using internal reforming reactions can maximize system efficiencies, some serious problems are involved. First, since the internal reforming reactions are an endothermic reaction at a high rate, most of them occur at the gas inlet part of a cell, and consequently, temperature deviations on the cell can become significant due to localized cooling so as to result in physical damages by thermal stresses. ${ }^{1)}$ Such temperature deviations are known to be the more severe, the higher the current density and the lower the fuel utilization. ${ }^{15)}$ Secondly, there is a problem of carbon deposition due to pyrolysis of hydrocarbon. ${ }^{6)}$ Carbon deposition occurs on $\mathrm{Ni}$ anode surfaces to interfere with 


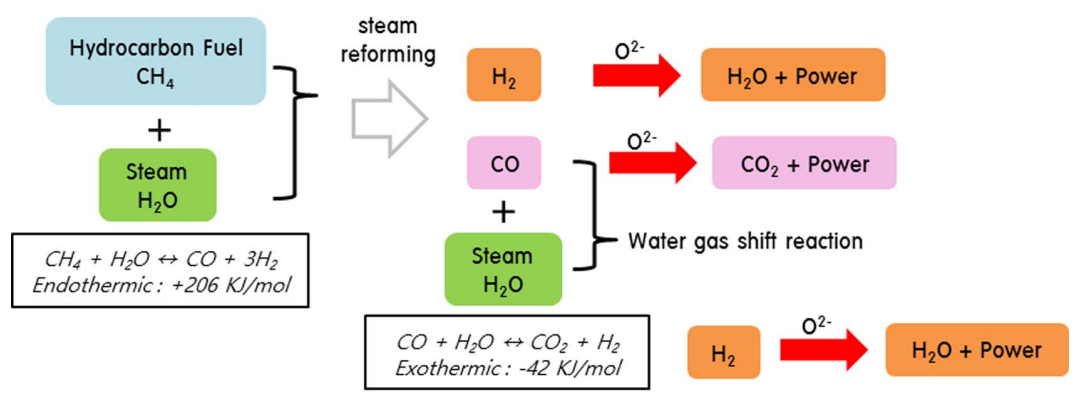

(a)

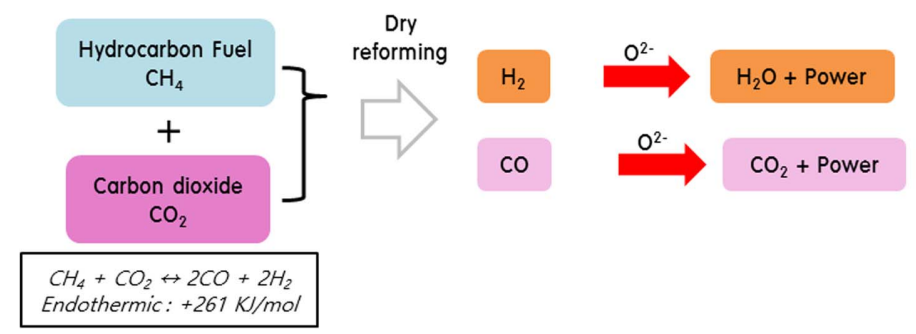

(b)

Fig. 1. Possible reaction pathway with (a) steam reforming and (b) dry reforming.

electrochemical reactions at the anode, resulting in reduction in SOFC performance and service life. Although expensive precious metal catalysts $(\mathrm{Pt}, \mathrm{Rh})$ are known to be more effective for prevention of carbon deposition than $\mathrm{Ni}$ as the anode component of SOFC, it is economically disadvantageous, prompting recent studies on augmentation of durability by adding dopants such as ceria. ${ }^{12)}$ Also, mechanism investigations should be carried out as well for reduced power density and increased degradation rates with internal reforming as compared with hydrogen, eventually for optimization of SOFC stack operation conditions.

In the present study, SOFC unit cells using methane and mixture gas(methane/carbon dioxide) as a fuel were fabricated to conduct evaluations of gas conversion rates and electrochemical performance for comparison/analysis, based on the results of which application feasibilities of hydrocarbon fuels to SOFC were considered.

\section{Experimental Procedure}

\subsection{Cell fabrication}

Solid oxide fuel cells used in the present study were composed of 5 layers as shown in Fig. 2. Fabrication of Anode Support Layer (ASL) was completed by uniaxial pressure forming after mixing $\mathrm{NiO}$ and $\mathrm{YSZ}\left(8 \mathrm{~mol} \% \mathrm{Y}_{2} \mathrm{O}_{3}+92 \mathrm{~mol} \%\right.$ $\mathrm{ZrO}_{2}$ ) powders in a ratio of $70: 30 \mathrm{Wt} \%$ and subsequent heat treatment at $950^{\circ} \mathrm{C}$ for $1 \mathrm{~h}$. Slurry for Anode Functional Layer(AFL) was prepared by grinding and mixing of 60 $\mathrm{Wt} \%$ of $\mathrm{NiO}$ and $40 \mathrm{Wt} \%$ of YSZ $40 \mathrm{Wt} \%$ with the use of a planetary ball mill followed by addition of butanol. The AFL was completed by drop-coating of thus-prepared slurry onto the surfaces of the heat-treated ASL and subsequent heat treatment at $950^{\circ} \mathrm{C}$ for $1 \mathrm{~h}$, while the electrolyte slurry with

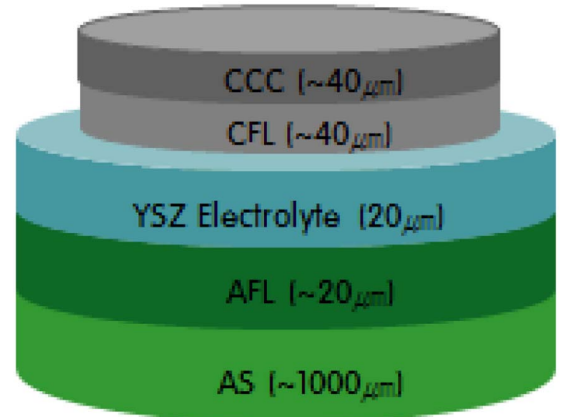

Fig. 2. Schematic of an anode supported cell (Ni-YSZ/YSZ/ LSM-YSZ).

mixing of YSZ and butanol was similarly subjected to dropcoating followed by sintering at $1460^{\circ} \mathrm{C}$ for $4 \mathrm{~h}$. Cathode Functional Layer (CFL) of LSM $\left(\mathrm{La}_{0.8} \mathrm{Sr}_{0.2} \mathrm{MnO}_{3-8}\right)+\mathrm{YSZ}$ and Current Collector(CC) of LSM were screen printed onto the surfaces of the sintered electrolyte, which were then heattreated at $1170^{\circ} \mathrm{C}$ and $1160^{\circ} \mathrm{C}$, respectively. The fabricated cell was of a button type with a total diameter of $25 \mathrm{~mm}$ and a cathode diameter of $14 \mathrm{~mm}$. The overall cell fabrication process is indicated in Fig. 3.

\subsection{Test setup}

Test fixtures were produced in-house for enhancing gas inlet /outlet and current collection, the components of which were as follows : 1) body made of alumina, 2) ceramic sealant, 3) Pt mesh - $\mathrm{Cu}$ wire for anode current collection, 4) $\mathrm{Ag}$ mesh -Ag wire for cathode current collection, 5) Anode/Cathode ceramic end plate composed of 9 gas channels. All performance evaluations were conducted at $800^{\circ} \mathrm{C}$, where tests were conducted after $\mathrm{NiO}$ of anode had been reduced for 


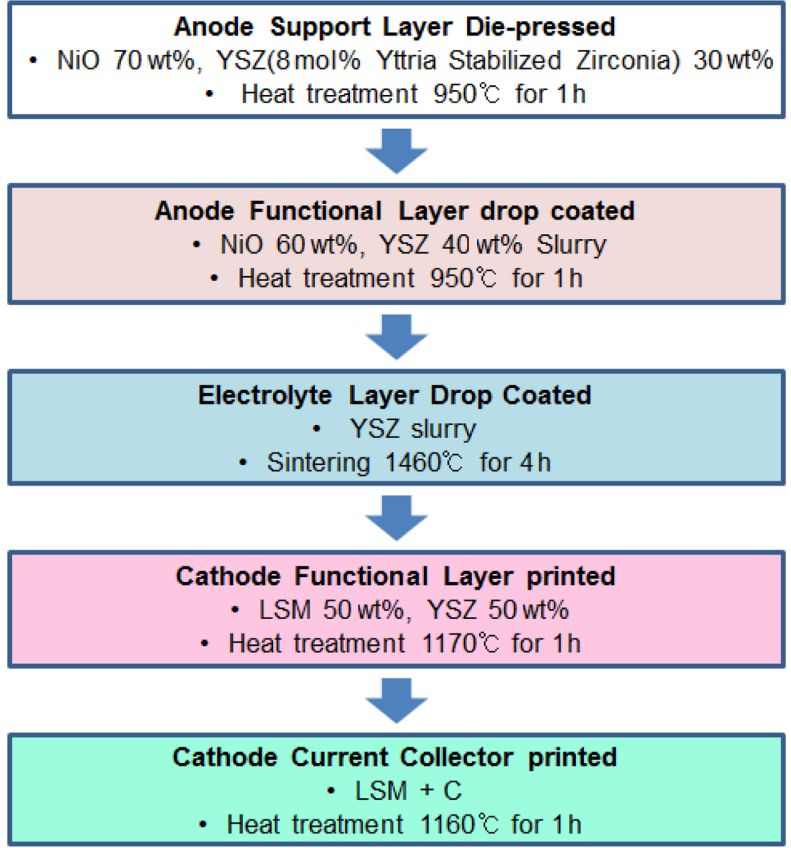

Fig. 3. Cell fabrication procedure.

about $2 \mathrm{~h}$ using a reducing gas $\left(\mathrm{H}_{2} 10 \%, \mathrm{~N}_{2} 90 \%\right)$. For methane internal reforming, steam was supplied in a $\mathrm{S} / \mathrm{C}$ (Steam to Carbon) ratio of $\sim 2$ by using the separately produced injection-type humidifier, while a heater was separately installed to prevent steam condensation in the gas inlet part. Measurement of conversion rates for internal reforming gas was conducted by using gas chromatography (GC, YL6500GC) after removing steam from the outlet gas by passing it through a cooler. To observe changes in power density and impedance(using Bio-Logic SP-240) as a function of fuel gas, $\mathrm{H}_{2}(\sim 300 \mathrm{cc} / \mathrm{min})$ and a mixture gas $\left(\mathrm{CH}_{4}+\mathrm{CO}_{2}, \sim 75 \mathrm{cc} / \mathrm{min}\right)$ were prepared as an Anode gas, while air ( $400 \mathrm{cc} / \mathrm{min})$ was used as a Cathode gas. Performance evaluation as a function of flow rate reduction $\left(\mathrm{H}_{2}\right.$ $\sim 100 \mathrm{cc} / \mathrm{min}$, mixture gas $\sim 25 \mathrm{cc} / \mathrm{min}$, air $\sim 133 \mathrm{cc} / \mathrm{min}$ ) was also conducted together. A schematic diagram for the test setup is shown in Fig. 4.

\section{Results and Discussion}

\subsection{Evaluation of conversion rates for internal reforming gas}

Figure 5 shows the results of analyzing the outlet gas at $800^{\circ} \mathrm{C}$ under an open circuit voltage, showing the ratio of $\mathrm{H}_{2}$ $\sim 67.65 \%, \mathrm{CH}_{4} \sim 9.78 \%$, $\mathrm{CO} \sim 5.14 \%, \mathrm{CO}_{2} \sim 12.70 \%$. As described earlier, not only hydrogen but also $\mathrm{CO}$ may be produced as a result of undergoing steam reforming, and $\mathrm{CO}_{2}$ may be produced by water gas shift reaction. In the present experiment, since $\mathrm{CO}_{2}$ was detected in an open-circuit condition, a part of $\mathrm{CO}$ produced from steam reforming can be seen to have been converted to $\mathrm{CO}_{2}$ by water gas shift reaction. According to the analysis results, about $4.73 \%$ of other $\left(\mathrm{N}_{2}\right.$ and $\left.\mathrm{O}_{2}\right)$ gases was detected, suggesting that air of the cathode had moved to the anode due to incomplete sealing.

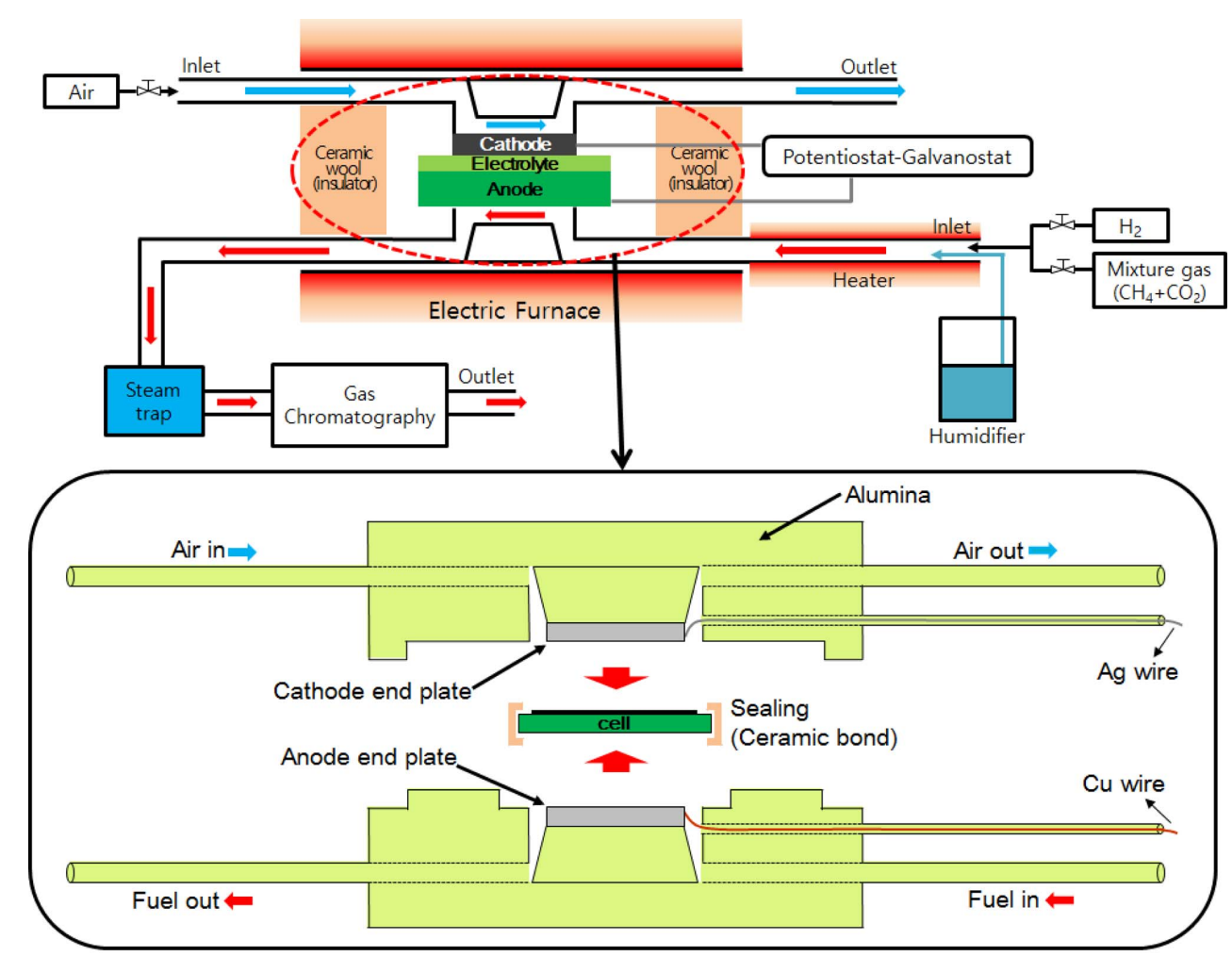

Fig. 4. Schematic of the test setup. 


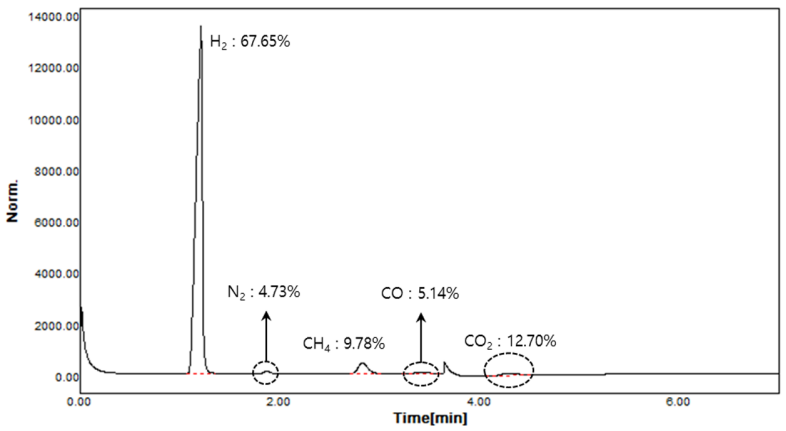

Fig. 5. GC result of internal reforming under open circuit condition.

When calculated on the basis of $9.78 \%$ of residual $\mathrm{CH}_{4}, \mathrm{CH}_{4}$ conversion rate could be calculated as $\sim 90 \%$, from the results of which a high rate of gas conversion may be seen possible by $\mathrm{Ni}$ catalyst alone as a component of the anode itself. However, the conversion rate will be reduced if the flow rate of inlet gas is increased to more than $25 \mathrm{cc} / \mathrm{min}$, while the residual $\mathrm{CH}_{4}$ is expected to be increased. It has been reported earlier that the gas conversion rates due to internal reforming are affected by the inlet gas flow rate (fuel utilization) as compared with the total surface area of the anode(Ni) for a fuel cell. ${ }^{15}$

\subsection{Comparison of power densities (Hydrogen vs. methane internal reforming)}

To consider performance changes upon supply of methane using internal reforming in comparison with hydrogen, basic electrochemical performance evaluations (I-V curve, impedance) were conducted. As shown in Fig. 1(a), if 100\% of $\mathrm{CH}_{4}$ was converted by steam reforming and water shift reaction through sufficient supply of $\mathrm{H}_{2} \mathrm{O}$, then 4 moles of $\mathrm{H}_{2}$ could be produced per 1 mole of $\mathrm{CH}_{4}$, i.e., 8 moles of electrons could be produced. Theoretically, an equivalent power density could be expected in comparison with hydrogen if $\mathrm{CH}_{4}$ was supplied by merely about $1 / 4$ of $\mathrm{H}_{2}$ flow rate. Based on such assumption, tests were conducted with the flow rate of $\mathrm{CH}_{4}$ being set at approximately $1 / 4$ of the hydrogen flow rate upon internal reforming. Supply of $\mathrm{CH}_{4}$ together with $\mathrm{CO}_{2}$ for internal reforming was implemented by mixture gas $\left(\mathrm{CH}_{4} 80 \%, \mathrm{CO}_{2} 20 \%\right)$, the ratio of which was set to similarly match the refined biogas ratio. Power density comparisons between the cell with $\mathrm{H}_{2}$ supply of $\sim 300 \mathrm{cc} / \mathrm{min}$ and the cell with mixture gas supply of $\sim 75 \mathrm{cc} / \mathrm{min}$ for internal forming are as shown in Fig. 6(a). Impedance was measured before power density test under an open circuit condition. While differences between ohmic resistance and non-ohmic resistance at a high frequency were comparable in both cases of hydrogen and internal reforming as shown in Fig. 6(b), some difference was noted at low frequencies $(10 \sim 0.1 \mathrm{~Hz})$. Impedance in the low-frequency range is related to compositions and flow rates of the supplied gas. ${ }^{16)}$ Maximum power density value of hydrogen supply cell was $\sim 0.377 \mathrm{~W} / \mathrm{cm}^{2}$, while that in the case of internally reformed mixture gas was $\sim 0.347 \mathrm{~W} / \mathrm{cm}^{2}$,

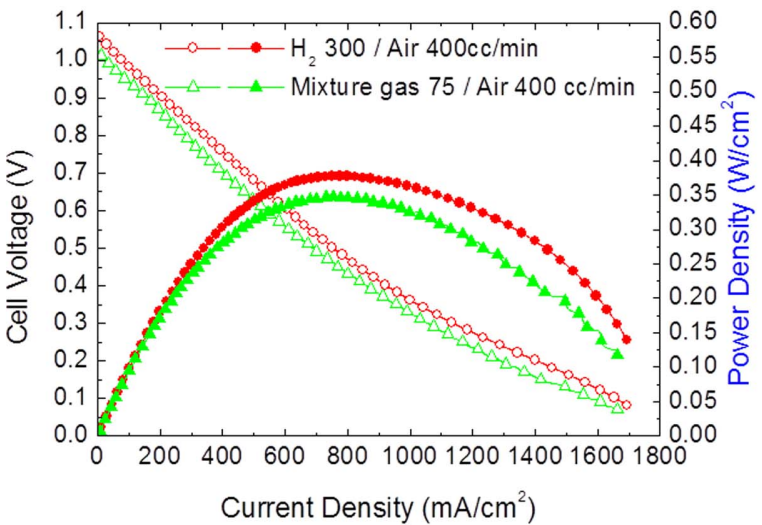

(a)

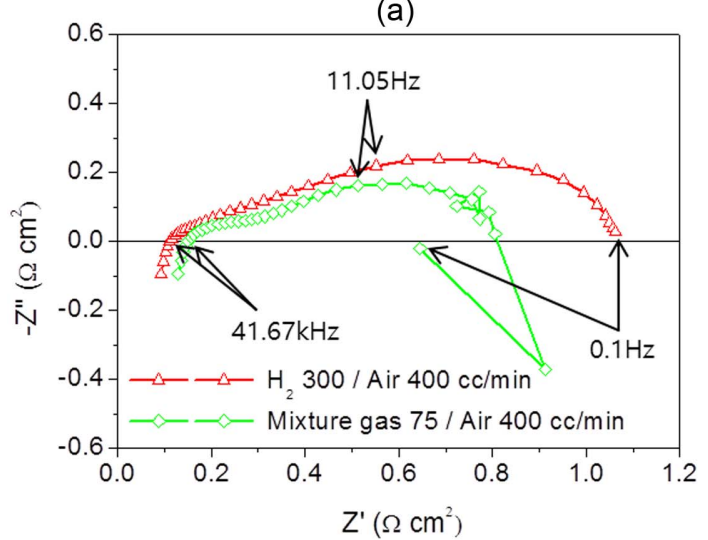

(b)

Fig. 6. (a) I-V curves and (b) impedance spectra under open circuit, with hydrogen fuel $(\sim 300 \mathrm{cc} / \mathrm{min})$ vs. internal reforming of mixture gas $(\sim 75 \mathrm{cc} / \mathrm{min})$.

thus showing an almost equivalent level. As can be seen from the I-V curve, slight differences in the power densities may be understood as a difference in the open-circuit voltage values, while the relatively low values of open-circuit voltage upon internal reforming are considered to be the result of an increase in the oxygen partial pressures at anode due to steam supply and residual steam. Since the mixture gas flow rate in the present experiment was $\sim 75 \mathrm{cc} /$ min, the gas conversion rate would have been less than $90 \%$. Therefore, short-term performance under an internal reforming condition (with a high conversion rate) considering fuel utilization are considered to be at an equivalent level as compared with hydrogen fuel. On the other hand, if the mixture gas flow rate was increased, the open-circuit voltages would be reduced further due to a reduction in conversion rates and an increase in the amounts of residual steam under such condition of a low fuel utilization, eventually resulting in power density reduction, as the steam flow rate would have to be increased proportionately to match the $\mathrm{S} / \mathrm{C}$ ratio. According to an article by Kyoto University research team, methane conversion rates for internal reforming methane at $800^{\circ} \mathrm{C}$ were measured to be less than $10 \%$ when $\mathrm{S} / \mathrm{C} \sim 2$, which is considered attributable to a high flow rate of methane in comparison with the anode area. ${ }^{3)}$ In 


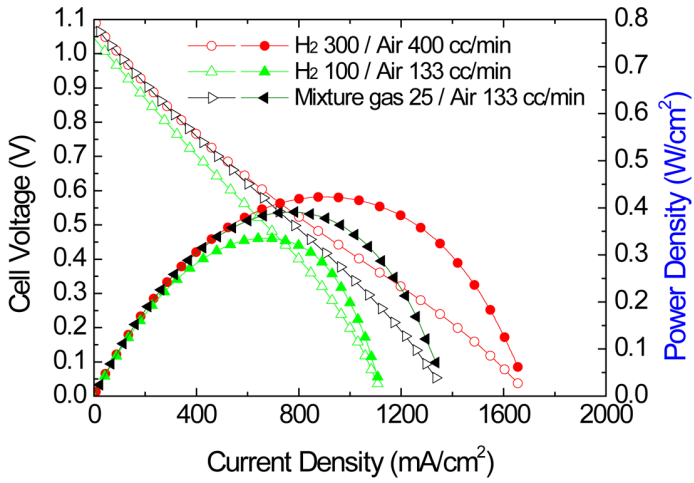

Fig. 7. I-V curves with hydrogen fuel $(\sim 300$ and $\sim 100 \mathrm{cc} / \mathrm{min})$ vs. internal reforming of mixture gas $(\sim 25 \mathrm{cc} / \mathrm{min})$.

such conditions of a low conversion rate, reduction in open circuit voltages and reduction in power densities compared with hydrogen were also shown to be remarkable. Therefore, we can say that performance(power density value) of fuel cells depends on methane and steam supply flow rates.

From the above viewpoint, power density tests were performed by reducing hydrogen and methane(steam) flow rates (i.e., increasing fuel utilization) (Fig. 7). Under the conditions of $\mathrm{H}_{2} \sim 300 \mathrm{cc} / \mathrm{min}, \mathrm{H}_{2} \sim 100 \mathrm{cc} / \mathrm{min}$, mixture gas $\left(\mathrm{CH}_{4} 80 \%, \mathrm{CO}_{2} 20 \%\right) \sim 25 \mathrm{cc} / \mathrm{min}, \mathrm{I}-\mathrm{V}$ curves were measured, where the resulting highest power densities were shown to be in the order of $\mathrm{H}_{2} \sim 300 \mathrm{cc} / \mathrm{min}$, mixture gas $\sim 25 \mathrm{cc} / \mathrm{min}$, $\mathrm{H}_{2} \sim 100 \mathrm{cc} / \mathrm{min}$ (based on the maximum power density). When the low flow rate conditions of $\mathrm{H}_{2} \sim 100 \mathrm{cc} / \mathrm{min}$ and mixture gas on $1 / 4$ level of hydrogen flow rate $\sim 25 \mathrm{cc} / \mathrm{min}$ were compared, the higher power density values were observed for the internal reforming operation unlike the results under the high flow rate conditions $\left(\mathrm{H}_{2} \sim 300 \mathrm{cc} / \mathrm{min}\right.$, mixture gas $\sim 75 \mathrm{cc} / \mathrm{min})$. Also, when compared within the mixture gas condition, better performance was observed at a low flow rate of $\sim 25 \mathrm{cc} / \mathrm{min}$, unlike expectations. The performance changes as a function of flow rate under $\mathrm{H}_{2} \sim 300$ and $100 \mathrm{cc} / \mathrm{min}$ conditions are considered attributable to the occurrence of a gas conversion overpotential which appeared as a result of failure to optimize flow channel design for the test fixture. ${ }^{16)}$ Overall, improvement in performance could be affirmed under the condition of a high utilization rate in the case of methane fuel with internal reforming performed, which suggests a correlation with the gas conversion rates described previously. Namely, the conversion rates were increased when the flow rate was low upon internal reforming while the amounts of residual steam were reduced, allowing the higher open-circuit voltages and power densities. However, it remains to be investigated by conducting additional experiments how the performance will be changed under the conditions of a higher fuel utilization rate than the present experimental conditions. Upon longterm operations, microstructures of $\mathrm{Ni}$ anode may be changed because of carbon deposition and steam supply of long duration, therefore performance degradation rate may be accelerated under internal reforming condition as compared with hydrogen fuel condition. Meanwhile, since steam is electrochemically produced at the anode by fuel cell reaction, the produced steam may be utilized for internal steam reforming. This recycling process allows us to gradually reduce external steam supply, eventually for the prevention of anode deterioration. ${ }^{6}$ Therefore, besides finding out conditions allowing short-term achievement of a high power density, studies are considered necessary for optimization of the stack operation conditions, such as current density, S/C ratio and fuel utilization, to secure a long-term durability.

\section{Conclusions}

In the present study, change aspects in power densities and deterioration rates of solid oxide fuel cells upon supply of a fuel using methane internal reforming have been investigated in comparison with those of hydrogen fuel. Under the flow rate conditions taking into account theoretical numbers of electrons produced per 1 mole of gas, the cell with supply of hydrogen fuel and the cell with methane internal reforming showed an equivalent level of power density values. In addition, performance improvement resulting from flow rate reduction was observed upon operation of internal reforming, and such phenomenon suggests that gas conversion rates were increased(residual steam and methane were reduced) to increase open-circuit voltages and power densities when the supply amounts of methane and steam were reduced. Consequently, setting of optimum operation conditions is important since the changes in performance can occur as a function of flow rate conditions (fuel utilization) upon internal reforming. Overall, the fuel cells composed of $\mathrm{Ni}$ anode were also affirmed to be capable of achieving equivalent performances in comparison with hydrogen fuel for a short term under the operation conditions of methane internal reforming at an appropriate flow rate with conversion rates taken into account.

\section{Acknowledgments}

This work was supported by the New \& Renewable Energy Core Technology Program of the Korea Institute of Energy Technology Evaluation and Planning (KETEP) granted financial resource from the Ministry of Trade, Industry \& Energy, Republic of Korea (No. 20143030031430) and by Basic Science Research Program through the National Research Foundation of Korea (NRF) funded by the Ministry of Science, ICT and Future Planning (2015 R1A1A1A05001187).

\section{REFERENCES}

1. K. Nikooyeh, A. A. Jeje, and J. M. Hill, "3D Modeling of Anode-supported Planar SOFC with Internal Reforming of Methane," J. Power Sources, 171 [2] 601-9 (2007).

2. T. Iida, M. Kawano, T. Matsui, R. Kikuchi, and K. Eguchi, 
"Internal Reforming of SOFCs Carbon Deposition on Fuel Electrode and Subsequent Deterioration of Cell," J. Electrochem. Soc., 154 [2] B234-41 (2007).

3. M. Kawano, T. Matsui, R. Kikuchi, H. Yoshida, T. Inagaki, and K. Equchi, "Direct Internal Steam Reforming at SOFC Anodes Composed of NiO-SDC Composite Particles," J. Electrochem. Soc., 154 [5] B460-65 (2007).

4. Y. Tabata, H. Orui, K. Watanabe, R. Chiba, M. Arakawa, and Y. Yamazaki, "Direct Internal Reforming Characteristics of SOFC with a Thin SASZ Electrolyte and a LNF Cathode," J. Electrochem. Soc., 151 [3] A418-21 (2004).

5. J. Liu and S. A. Barnett, "Operation of Anode-supported Solid Oxide Fuel Cells on Methane and Natural Gas," Solid State Ionics, 158 [1] 11-6 (2003).

6. J. M. Klein, M. Henault, P. Gelin, Y. Bultel, and S. Georges, "A Solid Oxide Fuel Cell Operating in Gradual Internal Reforming Conditions under Pure Dry Methane," Electrochem. Solid-State Lett., 11 [8] B144-47 (2008).

7. J.-H. Koh, B.-S. Kang, H. C. Lim, and Y.-S. Yoo, "Thermodynamic Analysis of Carbon Deposition and Electrochemical Oxidation of Methane for SOFC Anodes," Electrochem. Solid-State Lett., 4 [2] A12-15 (2001).

8. S. Park, J. M. Vohs, and R. J. Gorte, "Direct Oxidation of Hydrocarbons in a Solid-Oxide Fuel Cell," Nature, 404 26567 (2000).

9. S. Park, R. Craciun, J. M. Vohs, and R. J. Gorte, "Direct Oxidation of Hydrocarbons in a Solid Oxide Fuel Cell: I.
Methane Oxidation,” J. Electrochem. Soc., 146 [10] 3603-5 (1999).

10. R. J. Gorte, J. M. Vohs, and S. McIntosh, "Recent Developments on Anodes for Direct Fuel Utilization in SOFC," Solid State Ionics., 175 [1] 1-6 (2004).

11. A. L. Dicks, K. D. Pointon, and A. Siddle, "Intrinsic Reaction Kinetics of Methane Steam Reforming on a Nickel/Zirconia Anode," J. Power Sources, 86 [1] 523-30 (2000).

12. S. C. Singhal and K. Kendall, "High Temperature Solid Oxide Fuel Cell: Fundamentals, Design and Applications," Elsevier, Oxford, 2004.

13. T. Takeguchi, R. Kikuchi, T. Yano, K. Eguchi, and K. Murata, "Effect of Precious Metal Addition to Ni-YSZ Cermet on Reforming of $\mathrm{CH} 4$ and Electrochemical Activity as SOFC Anode," Catal. Today, 84 [3] 217-22 (2003).

14. K. P. Recknagle, E. M. Ryan, B. J. Koeppel, L. A. Mahoney, and M. A. Khaleel, "Modeling of Electrochemistry and Steam-methane Reforming Performance for Simulating Pressurized Solid Oxide Fuel Cell Stacks," J. Power Sources, 195 [19] 6637-44 (2010).

15. H.-T. Lim, C. Yang, S. C. Hwang, and Y.-J. Choi, "Experimental Study of Internal Reforming on Large-area Anode Supported Solid Oxide Fuel Cells," Fuel Cells, in press.

16. H.-T. Lim, S. C. Hwang, and J. S. Ahn, "Performance of Anode-supported Solid Oxide Fuel Cell in Planar-cell Channel-type Setup," Ceram. Int., 39 S659-62 (2013). 